\title{
Penggunaan Inovasi Nilai Untuk Menciptakan Keunggulan Kompetitif Pada Strategi Blue Ocean (Studi pada Maskapai Penerbangan Air Asia)
}

\author{
Dwi Tesna Andini \\ STMIK ASM Mataram \\ dwitesnaandini@yahoo.co.id
}

\begin{abstract}
Abstrak - Fenomena potensi pertumbuhan bisnis transportasi udara di Indonesia semakin marak diperbincangkan. Persaingan antar maskapai penerbangan terjadi. Perusahaan industri penerbangan memiliki strategi untuk tetap bertahan di pasar, salah satu strategi yang digunakan adalah menerapkan konsep Low Cost Carrier (LCC). Air Asia adalah salah satu maskapai penerbangan yang sukses menerapkan konsep LCC. Salah satu meningkatkan kemampuan perusahaan serta menciptakan segmen pasar tersendiri adalah dengan memberikan inovasi nilai. Inovasi nilai meruapakan batu pijak dari strategi blue ocean. Tujuan utama dari penelitian ini menggunakan kerangka strategi blue ocean untuk menganalisis bagaimana menggunakan inovasi nilai untuk menciptakan keunggulan kompetitif pada maskapai penerbangan Air Asia. Jenis peneliian menggunakan deskriptif kuantitatif. Subjek penelitian maskapai penerbangan Air Asia, objek penelitian pengguna Air Asia. Teknik pengumpulan data dilakukan melalui kuisioner dan wawancara. Analisis data pada metode kuantitatif menggunakan analisis regresi linear sedangkan untuk metode kualitatif menggunakan alisis SWOT dan analisis strategi blue ocean. Hasil dari penelitian ini adalah variabel inovasi nilai $(X)$ mempunyai pengaruh yang signifikan terhadap keunggulan kompetitif (Y) pada maskapai penerbangan Air Asia. Hasil untuk penelitian kualitatif. Hasil untuk analisis SWOT, Air Asia tetap mampu mempertahankan kesuksesannya mengingat kekuatan yang dimiliki, seperti brand image Air Asia sebagai maskapai penerbangan dengan biaya rendah. Strategi yang digunakan oleh Air Asia mampu menciptakan keunggulan kompetitif.
\end{abstract}

Kata Kunci - Inovasi Nilai, Keunggulan Kompetitif, Analisis SWOT, Blue Ocean Strategy. 


\section{Latar Belakang}

Strategi adalah inti dari keberhasilan atau kegagalan suatu perusahaan. Salah satu strategi perusahaan agar mampu bertahan di pasar industri adalah dengan menerapkan konsep Low Cost Carrier (LCC). Dalam beberapa situs penerbangan, Air Asia memulai konsep LCC pada akhir tahun 2001. Air Asia adalah maskapai penerbangan murah asal Malaysia.

Konsep LCC juga dilakukan oleh industri lain seperti Lion Air dan Citilink. Di tengah persaingan ketat tersebut Air Asia memperlebar rute penerbangan ke luar negeri. Rute penerbangan Air Asia Indonesia adalah $80 \%$ internasional dan 20\% domestik. Maskapai penerbangan Air Asia mendapatkan value innovation yang baik bagi perushaaan dan dapat menciptakan blue ocean yang baik. Untuk mewujudkan blue ocean melalui inovasi nilai dibutuhkan kerja kerangka kerja analisis yang disebut kerangka kerja empat langkah (Kim dan Mauborgne, 2005) [1]. 1. Kurangi: maskapai penerbangan Air Asia tidak menggunakan agenagen penjualan tiket sehingga dapat mengurangi biaya operasional. 2. Hapuskan: Air Asia tidak menyediakan makanan dan minuman di dalam pesawat karena karena waktu tempuh relatif singkat. 3. Tingkatkan: Air Asia meningkatkan pelayanan melalui sistem online sehingga memudahkan masyarakat dalam hal pemesanan. 4. Ciptakan: maskapai penerbangan Air Asia menawarkan biaya perjalan yang murah baik perjalanan dalam negeri maupun dalam luar negeri. Dengan moto yang dimiliki "Now Every One Can Fly".

\section{B. Rumusan Masalah}

Rumusan masalah penelitian adalah bagaimana pengaruh inovasi nilai untuk menciptakan keunggulan kompetitif pada strategi blue ocean (studi pada maskapai penerbangan Air Asia.

\section{Tujuan Penelitian}

Tujuan penelitian adalah menggunakan kerangka strategi blue ocean untuk menganalisis bagaiamana menggunakan inovasi nilai untuk menciptakan keunggulan kompetitif.

\section{Manfaat penelitian}

1. Manfaat teoritis: memberikan data dan informasi serta menambah referensi kepustakaan mengenai value inovation dan keunggulan kompetitif pada blue ocean sebagai bahan studi dalam melakukan penelitian selanjutnya dengan pengembangan yang lebih variatif.

2. Manfaat praktis: sebagai bahan masukan dan pertimbangan dalam meningkatkan inovasi nilai untuk mendapatkan keunggulan kompetitif pada strategi blue ocean, agar dapat mempertahankan konsumen. Sebagai bahan masukan untuk meningkatkan kualitas pelayanan agar tetap bertahan pada blue ocean.

\section{Kerangka Teori}

\section{a. Keunggulan Kompetitif}

Keunggulan kompetitif pada dasarnya berkembang dari nilai yang mampu diciptakan oleh sebuah perusahaan untuk pembelinya yang melebihi biaya perusahaan dalam menciptakannya, (Porter, 1994) [2]. Umumnya, sebuah perusahaan mampu untuk mempertahankan keunggulan kompetitif hanya untuk periode tertentu saja. Jadi tidaklah cukup untuk memiliki keunggulan kompetitif. Perusahaan harus berusaha untuk memiliki keunggulam kompetitif berkelanjutan (sustainable competitve advantage).

\section{b. Inovasi Nilai}

Inovasi nilai merupakan batu pijak untuk samudera biru. Inovasi nilai menurut Kim dan Mauborgne (2005) diciptakan dalam wilayah di mana tindakan perusahaan secara positif mempengaruhi struktur biaya dan tawaran bagi pembeli. Penghematan biaya dilakukan dengan menghilangkan titik persaingan dalam industri. Nilai pembeli ditingkatkan dengan menambah dan menciptakan elemen-elemen yang belum pernah ditawarkan oleh industri.

\section{c. Strategi Blue Ocean and Red Ocean}

Tabel 1: Perbedaan Blue Ocean Strategi dan Red Ocean Strategy

\begin{tabular}{|c|c|}
\hline Red Ocean Strategy & $\begin{array}{c}\text { Blue Ocean } \\
\text { Strategy }\end{array}$ \\
\hline $\begin{array}{l}\text { Bersaing dalam ruang } \\
\text { pasar yang sudah ada. }\end{array}$ & $\begin{array}{l}\text { Menciptakan ruang } \\
\text { pasar yang belum } \\
\text { ada pesaingnya. }\end{array}$ \\
\hline Memerangi kompetisi & $\begin{array}{l}\text { Menjadikan } \\
\text { kompetisi } \\
\text { relevan }\end{array}$ \\
\hline $\begin{array}{l}\text { Mengeksploitasi } \\
\text { permintaan yang ada }\end{array}$ & $\begin{array}{lr}\text { Menicptakan } & \text { dan } \\
\text { menangkap } \\
\text { permintaan } \\
\text { baru }\end{array}$ \\
\hline $\begin{array}{l}\text { Memilih antara nilai- } \\
\text { biaya (value cost trade- } \\
\text { off) }\end{array}$ & $\begin{array}{l}\text { Mendobrak } \\
\text { pertukaran nilai-biaya }\end{array}$ \\
\hline $\begin{array}{l}\text { Memadukan } \\
\text { keseluruhan } \\
\text { kegiatan dengan pistem } \\
\text { strategis } \\
\text { diferensiasi atau biaya } \\
\text { rendah. }\end{array}$ & $\begin{array}{l}\text { Memadukan } \\
\text { keseluruhan sistem } \\
\text { kegiatan dalam } \\
\text { mengejar diferensiasi } \\
\text { dan biaya rendah. }\end{array}$ \\
\hline
\end{tabular}

\section{d. Enam Prinsip Strategi Blue Ocean}

1). Kanvas Strategi. Kanvas Strategi adalah kerangka aksi sekaligus diagnosis untuk membangun strategi samudera biru yang baik. Kanvas strategi berfungsi untuk merangkum situasi terkini dalam ruang pasar yang sudah dikenal. 
Kanvas strategi ini akan memberikan sebuah peta untuk memahami faktor-faktor apa yang menjadi ajang persaingan.

2). Fokus Pada Gambaran besar, Bukan Pada Angka. Prinsip ini merupakan kunci untuk mengurangi risiko perencanaan investasi tenaga dan waktu yang terlalu besar dengan hasil hanya berupa langkah taktis samudera merah. Pendekatan ini secara konsisten menghasilkan strategi yang membuka kreativitas dari beragam jenis orang dalam suatu organisasi, membuka perusahaan kepada samudera biru, dan mudah dipahami serta dikomunikasikan untuk bisa diterapkan secara efektif.

3). Menjangkau Melampaui Permintaan yang Ada. Hal ini merupakan komponen kunci dalam mencapai inovasi nilai. Untuk mencapai hal ini, perusahaan harus menentang dua praktik strategi konvensional. Pertama, berfokus pada konsumen yang ada. Kedua, dorongan mempertajam segmentasi demi mengakomodasi perbedaan di pihak pembeli.

4). Menjalankan rangkaian strategis Secara Benar. Perusahaan perlu membangun strategi samudera biru mereka dalam rangkaian utilitas pembeli, harga, biaya, dan pengadopsian.

5). Mengatasi Hambatan Utama Organisasi. Terdapat empat rintangan organisasi bagi eksekusi strategi yang telah ditetapkan, yaitu: rintangan kognitif, rintangan sumber daya, rintangan politik, dan rintangan motivasional.

6). Mengintegrasikan Eksekusi ke dalam Strategi. Pada prinsip ke enam terdapat beberapa pengaruh yang ditimbulkan oleh proses adil terhadap sikap dan perilaku orang ketika manajemen mengeksekusi strategi.

e. Model Penelitian

Inovasi nilai merupakan batu pijak untuk samudera biru. Inovasi nilai menurut Kim dan Mauborgne (2005) diciptakan dalam wilayah di mana tindakan perusahaan secara positif mempengaruhi struktur biaya dan tawaran bagi pembeli. Variabel inovasi nilai dibentuk berdasarkan nilai pembeli dan biaya.

Menurut Porter (1994) keunggulan kompetitif adalah kemampuan suatu perusahaan untuk meraih keuntungan ekonomis di atas laba yang mampu diraih oleh pesaing di pasar dalam industri yang sama. Beberapa cara untuk memperoleh strategi generik yang diklasifikasikan dalam tiga kategori, yaitu cost leadership, diferensiasi, dan fokus untuk dapat meraih keunggulan kompetitif.

Gambar 1: Model Penelitian

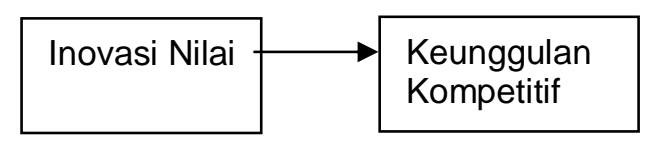

3. Metode Penelitian

\section{a. Objek dan Subjek Penelitian}

Objek penelitian ini yaitu maskapai penerbangan Air Asia. Subjek penelitiannya adalah pengguna maskapai penerbangan Air Asia, tour guide, event organizer, dan agen tiket.

\section{A. Teknik Pengambilan sampel/Narasumber}

Pada penelitian kuantitatif cara pengambilan sampel yaitu dengan accidental/convenience sampling. Accidental/convenience sampling adalah prosedur sampling yang memilih sampel dari orang atau unit yang paling mudah dijumpai atau diakses, (Santoso dan Tjipjono, 2001) [3]. Sampel pada penelitian ini adalah pengguna maskapai penerbangan Air Asia.

Dalam penelitian ini mengambil sampel sejumlah 96 responden. Besarnya ukuran sampel sebanyak 96 responden dihitung dengan rumus (Djarwanto dan Pangestu, 1996) [4].

$\mathrm{n}={\frac{(\mathrm{z} 1 / 2 \alpha)^{2}}{\mathrm{E}}}^{2}$

Keterangan:

$\mathrm{n}=$ banyaknya sampel yang diperlukan

$\mathrm{E}=$ besarnya kesalahan yang dapat ditolerir

$\alpha=$ tingkat konfidensi yang digunakan

Dalam penelitian ini besarnya kesalahan yang digunakan $(E)$ sebesar $1 \%$ dan distribusi normal $(\alpha)$ yang digunakan adalah 0,50 . Jadi besarnya sampel yang digunakan adalah sebagai berikut.

$$
\begin{aligned}
& \mathrm{n}=\frac{(1,96 \times 0,05)^{2}}{0,01} \\
& \mathrm{n}=96,04 \text { dibulatkan menjadi } 96 .
\end{aligned}
$$

Pada Penelitian kualitatif cara pengambilan sampel dengan teknik purposive sampling, yaitu pemilihan sampel berdasarkan pada karakteristik tertentu yang dianggap mempunyai sangkut paut dengan karakteristik populasi yang telah diketahui sebelumnya, (Margono, 2004) [5]. Narasumber penelitian ini adalah pengguna Air Asia tour guide, event organizer, dan agen tiket. Dengan karakter menggunakan maskapai penerbangan Air Asia dan pernah menggunakan maskapai lainnya.

\section{b. Teknik Pengumpulan Data}

1). Kuisioner dibuat menggunakan skala Likert, menurut Sugiyono (2014) [6], skala Likert digunakan untuk mengukur sikap, pendapat, dan persepsi seseorang atau kelompok orang tentang fenomena sosial.

2). Wawancara adalah percakapan dengan maksud tertentu di mana percakapan dilakukan oleh dua pihak yaitu, pewawancara sebagai pengaju pertanyaaan dan terwawancara sebagai pemberi jawaban atas pertanyaan, Moloeng (2007) [7].

\section{c. Definisi Operasional}

\section{1). Inovasi Nilai}

Dimensi dari inovasi nilai yaitu nilai pelanggan 
dan biaya.

a). Nilai pelanggan (customer value) adalah preferensi dan evaluasi terhadap atribut produk, kinerja dan konsekuensi dari pengguna, (Robert. 1997) [8]. Indikator variabel customer value (Pramudita, 2013) [9] pada instrumen penelitian ini adalah: emotional value, social value, quality/performance value, dan price/value of money.

b). Biaya yaitu pengorbanan sumber ekonomis yang diukur dengan satuan uang untuk memperoleh barang atau jasa yang diharapkan memberikan manfaat saat ini maupun yang akan datang (Mulyadi, 2002) [10]. Indikator variabel biaya menurut (Hoffman dan Batenson, 1997) [11] yaitu: biaya ekonomis/moneter, biaya waktu, biaya energi yang dikeluarkan oleh konsumen, dan biaya fisik.

2). Keunggulan Kompetitif

Dimensi dari keunggulan kompetitif yaitu nilai kualitas pelayanan, diferensiasi, dan citra perusahaan, (Kadarningih, 2013) [12].

a). Kualitas pelayanan menurut Parasuraman, dkk dalam Kotler (1995) [13]. Kualitas pelayanan adalah strategi yang mendasar untuk sukses dan bertahan dalam lingkungan persaingan bisnis yang ketat. Indikator dari kualitas pelayanan menurut Parasuraman, dkk dalam Kotler (1995), yaitu: bukti fisik, keandalan, daya tanggap, jaminan, kepercayaan

b). Diferensiasi dapat tercapai bila perusahaan juga memperhatikan aktivitas yang bernilai (activity value) dari kegiatan usaha yang terdiri dari aktivitas utama dan aktivitas pendukung, yang merupakan rantai nilai (value chain). Value chain berhubungan dengan aktivitas-aktivitas antara lain supplier (pemasok), channels (jaringan distribusi, pemasaran) dan buyers (pembeli) (Porter, 1985) [14]. Indikator variabel diferensiasi pada instrumen penelitian ini (Kadarningsih, 2013): layanan jasa, rute penerbangan, kegiatan inovasi produk.

c). Citra erusahaan menurut Smith dan Barclay (1999) [15]

mengkaitkan hubungan citra perusahaan dengan penjualan melalui pesan yang efektif. Indikator variabel citra perusahaan pada instrumen ini (Kadarningsih, 2013): kesadaran merek, reputasi perusahaan, dan kemampuan manajemen.

\section{d. Uji Instrumen}

Uji validitas dan reliabilitas instrumen dilakukan untuk memperoleh data yang akurat. Validitas adalah sebuah alat untuk menguji seberapa baik instrumen yang dikembangkan dalam mengukur konsep tertentu (Sekaran, 2006) [16]. Sebuah instrumen dikatakan valid apabila mampu mengukur apa yang diinginkan dan mampu mengungkap data yang diteliti secara tepat. Uji validitas dalam penelitian ini dilakukan dengan menggunakan pearson correlation product moment dengan bantuan SPSS 17. Instrumen penelitian dikatakan valid apabila nilai signifikansi lebih kecil dari 5\%.

Uji reliabilitas yaitu menguji seberapa konsisten satu seperangkat pengukuran mengukur secara konsisten suatu konsep yang diukur, (Susanto, 2013). Nilai reliabilitas suatu konstruk dikatakan reliabel apabila koefesien cronbach's alpha $>0,7$ (Gozali, 2011) [17].

\section{e. Analisa Data}

Analisa regresi linear adalah metode statitistik yang berfungsi untuk menguji sejauh mana hubungan sebab akibat antara variabel inovasi nilai (X) terhadap variabel keunggulan kompetitif (Y).

Analisis kualitatif dalam penelitian ini menggunanakan analisis (Strength, Weakness, Opportunities, Threats) SWOT untuk mengidentifikasikan berbagai faktor lingkungan internal (kekuatan dan kelemahan) serta faktor lingkungan eksternal (peluang dan ancaman) secara sistematis, yang selanjutnya akan digunakan untuk merumuskan strategi perusahaan. Analisis SWOT dilakukan untuk menganalisis lingkungan bisnis sebagai dasar untuk merancang strategi dan program kerja.

Kemudian menggunakan analisa blue ocean, yaitu strategi kanvas, skema hapuskan-kurangitingkatkan-ciptakan, tiga ciri blue ocean yang baik: fokus, divergensi, dan moto yang memikat.

\section{Hasil dan Pembahasan}

\section{a. Gambaran Umum Perusahaan}

PT Air Asia Indonesia dibentuk pada bulan September 1999 sebagai perusahaan lokal di Indonesia. Visi: menjadi maskapai penerbangan berbiaya hemat di Asia dan melayani 3 juta orang yang sekarang dilayani dengan konektivitas yang kurang baik dan tari yang mahal. Misi : menjadi perusahaan terbaik untuk bekerja di mana para karyawan dianggap anggota keluarga besar, menciptakan brand ASEAN yang diakui secara global, mencapai tarif terhemat sehingga semua orang bisa terbang berasama Air Asia, mempertahankan produk berkualitas tinggi, menggunakan teknologi untuk mengurangi pembiayaan dan meningkatkan kualitas layanan. Moto: Now Everyone Can Fly.

\section{b. Hasil Uji Kualitas Instrumen}

Uji validitas variabel Inovasi Nilai $(X)$ dengan metode pearson correlations dapat diketahui instrumen yang diujikan adalah valid (sahih) karena nilai signifikan lebih kecil dari 0,05.

Uji validitas variabel keunggulan kompetitif $(Y)$ dengan metode pearson correlations dapat diketahui bahwa instrumen yang diujikan adalah 10 item pertanyaan dinyatakan valid (sahih) karena nilai signifikansi kurang dari 0,05 dan terdapat 1 instrumen yang tidak valid, untuk itu peneliti membuang item pertanyaan yang tidak valid karena 
kriteria variabel masih bisa terpenuhi oleh pertanyaan yang tersisa.

\section{c. Hasil Regresi dan Hipotesis Penelitian}

Nilai cronbach's alpha untuk variabel inovasi nilai (X) sebesar 0.768 dan keunggulan kompetitif $(\mathrm{Y})$ sebesar 0.802. Nilai cronbach's alpha kedua variabel tersebut di atas 0,70 maka instrumen penelitian yang digunakan tersebut reliable.

Gambar 2: Hasil Reliabeltas Variabel

\begin{tabular}{|c|c|c|c|}
\hline VARIABEL & $\begin{array}{c}\text { STANDARDI } \\
\text { ZED } \\
\text { COEFFICIEN } \\
\text { TS (BETA) }\end{array}$ & T & SIG. \\
\hline $\begin{array}{c}\text { INOVASI NILAI } \\
(\mathrm{X})\end{array}$ & 0.635 & 7.976 & $\begin{array}{c}0.00 \\
0\end{array}$ \\
\hline $\mathrm{R}$ & \multicolumn{3}{|c|}{0.635} \\
\hline R SQUARE & \multicolumn{3}{|c|}{0.404} \\
\hline
\end{tabular}

Hasil analisis regresi yang telah dilakukan, maka persamaan regresi yang dapat disusun adalah:

\section{$\mathrm{Y}=0,635 \mathrm{X}+\mathrm{e}$}

Berdasarkan persamaan regresi tersebut dapat diinterpretasikan bahwa nilai koefisien beta untuk variabel inovasi nilai $(X)$ sebesar 0,635 . Hasil ini menunjukkan nilai positif, artinya apabila variabel inovasi nilai $(X)$ mengalami peningkatan, maka keunggulan kompetitif ( $(Y)$ pada maskapai penerbangan Air Asia juga meningkat.

Selanjutnya dilakukan pengujian hipotesis menggunakan uji t atau uji parsial yaitu uji hipotesis yang digunakan untuk mengetahui pengaruh variabel independen terhadap variabel dependen. Hipotesis penelitian menyatakan bahwa ada pengaruh signifikan variabel inovasi nilai (X) terhadap keunggulan kompetitif pada maskapai penerbangan Air Asia. Hipotesis tersebut dapat diterima karena nilai signifikansi variabel gaya inovasi nilai $(X)$ berada di bawah 0.05 , yaitu 0,00 yang berarti bahwa hasil pengujian signifikan pada taraf nyata $5 \%$ sehingga dapat dijelaskan variabel inovasi nilai $(X)$ mempunyai pengaruh positif dan signifikan terhadap keunggulan kompetitif pada maskapai penerbangan Air Asia, sehingga dapat disimpulkan hipotesis dapat diterima.

Berdasarkan pengujian regresi dengan bantuan program SPSS diperoleh nilai $R$ square sebesar 0,404 . Hal ini menunjukkan bahwa pengaruh inovasi nilai terhadap keunggulan kompetitif sebesar $40,4 \%$, sedangkan sisanya sebesar $59,6 \%$ dipengaruhi oleh variabel lain yang tidak masuk dalam penelitian.

\section{d. Hasil Kualitatif}

Pada penelitian kualitatif, peneliti melakukan wawancara terhadap narasumber yaitu Martika sebagai pengguna, Setiawan sebagai event organizer, Yasir sebagai tour guide, dan Iwan sebagai agen tiket. Peneliti juga mengumpulkan data dari berbagai sumber di internet. Seperti komentar Isaac dan Lili pada majalah 3sixty dan Eddy pada kompasiana. Berikut data yang diperoleh:

1). Kenyamanan saat dalam berada di kabin pesawat

Salah satu alasan yang membuat pelanggan menggunakan maskapai penerbangan Air Asia karena mereka merasa nyaman saat berada dalam kabin pesawat. Ukuran tempat duduk yang disediakan oleh Air Asia lebih sempit dibandingkan yang lain, namun hal ini tidak mengurangi kenyamanan selama dalam perjalanan. Menurut Martika saat wawancara pada 30 April 2016 mengatakan bahwa ia merasa nyaman selama berada dalam kabin pesawat dan tempat duduk yang disediakan juga sesuai dengan kebutuhan. Rasa nyaman selama di kabin pesawat disebabkan oleh maskapai yang digunakan oleh Air Asia tergolong baru dengan tipe Airbus.

Air Asia mengoperasikan armada Airbus A320, salah pesawat yang dapat diandalkan, aman, dan maju secara teknologi. Seperti yang diungkapkan oleh salah satu pengguna bernama Yasir saat diwawancara pada 2 April 2016 mengatakan harga sebanding dengan kualitas, hampir semua pesawat Air Asia Airbus masih tergolong baru dan itu yang membuat nyaman.

Kenyamanan saat berada dalam kabin pesawat juga Air Asia juga diperkuat oleh pemaparan Setiawan menyatakan bahwa warna merah yang menjadi dominasi kabin pesawat membuatnya semangat.

2). Sistem Reservasi Tiket Secara Online

Martika menerangkan pesan tiket dengan sistem reservasi online memudahkan dalam memilih harga yang sesuai. Dengan sistem tersebut Martika lebih memilih untuk memesan secara online dibandingkan harus ke agen tiket. Menurut Setiawan, reservasi secara online tersebut memudahkan penumpang dalam hal pemesanan tiket. Hasil wawancara dengan Iwan salah satu agen tiket di Yogyakarta pada 2 April 2016 menyatakan bahwa dari segi penjualan peminat Air Asia sedikit, karena penumpang lebih memilih reservasi secara online dibanding datang langsung ke agen tiket.

Maskapai penerbangan Air Asia menekankan penjualan dengan menggunakan tiket secara langsung. Membangun sedikit konter pembelian tiket dan tidak bekerjasama dengan agen tiket dan lebih mengutamakan pemesanan tiket melalu call center dan internet untuk menekan biaya.Iwan menjelaskan keuntungan dari penjualan tiket Air Asia sekitar 1$2 \%$.

\section{3). Keterampilan Karyawan}

Setiawan menjelaskan karyawan Air Asia sigap dalam memberikan pelayanan. Saat penumpang mengalami kesulitan dalam membawa barang 
bawaan, pramugari Air Asia dengan cepat membantu para penumpang.

Martika juga menceritakan bahwa karyawan Air Asia sigap dalam melayani pelanggan. Hal ini terbukti saat Martika ingin menukar tempat duduk, dengan sigap karyawan Air Asia mengurus perpindahan tempat duduk tersebut dengan syarat menyertakan kode booking.

\section{4). Ontime Performance}

Menurut Iwan selama ini belum ada keluhan pelanggan mengenai keterlambatan keberangkatan. Setiawan berpendapat waktu pesawat Air Asia adalah sekitar 25 menit, dibandingkan dengan maskapai reguler yaitu 1 jam.

\section{5). Rute Penerbangan Air Asia}

Yasir berpendapat sejauh ini Air Asia menguasai rute di Asia Tenggara. Air Asia merupakan maskapai penerbangan asal Malaysia dengan memiliki rute $20 \%$ domestik dan $80 \%$ internasional. Martika menjelaskan rute penerbangan yang ditawarkan oleh Air Asia bertambah dari tahun ke tahun.

\section{6). Harga Tiket Air Asia}

Setiawan menuturkan dalam dalam bisnis maskpai ada full service, medium, dan low cost, untuk di kelas low cost Air Asia pemenang. Setiawan pernah mendapat promo yang disediakan Air Asia. Setiawan berpendapat bahwa persepsi masyarakat yang dulu keluar negeri mahal kemudian Air Asia merubah persepsi dengan tiket murah yang ditawarkan.

Yasir juga menceritakan sering merasakan promo yang ditawarkan oleh Air Asia baik itu perjalan dalam negeri maupun luar negeri. Eddy Roesdiana menceritakan perasannya pada Kompasiana online. Pengalamannya terbang Air Asia sebanyak 44 kali membuat Eddy merasa beruntung dengan harga yang ditawarkan oleh maskapai asal Malaysia itu. Di sisi lain Isaac memaparkan pengalamannya terbang bersama Air Asia. Berkat maskapai LCC tersebut ia bisa keliling Indonesia dan Malaysia dengan biaya murah.

\section{E. Analisis SWOT}

\section{Strength}

a. Brand Image. Sebagai pelopor maskapai penerbangan harga tiket penerbangan yang murah, sekarang semua bisa terbang menggunakan Air Asia. Sehingga muncul di benak masyarakat jika ingin melakukan perjalanan keluar negeri moda transportasi yang digunakan adalah Air Asia.

b. Kenyamanan penggunaan website. Saat proses pembelian tiket di Air Asia, calon penumpang mendapatkan rincian biaya yang dikeluarkan. Calon penumpang dapat melakukan pembayaran melalui kartu kredit dan kartu debit.Pemesanan tiket bisa melalui website, callcenter, biro perjalanan dan melalui SMS.

c. Air Asia memiliki inovasi baru dengan cara check in online. Dua minggu sebelum keberangkatan calon penumpang sudah bisa check in secara online. Sehingga orang tidak perlu terburu-buru datang ke bandara untuk check in.

2. Weakness

a. Tingkat pelayanan terbatas dikarenakan harga tiket yang murah, pelayanan pada konsumen pun terbatas. Penumpang yang ingin mendapat fasilitas lebih dikenakan biaya tambahan.

b. Delay penerbangan. Salah satu analisa yang mungkin terjadi kendala teknis dari keterlambatan persiapan pesawat pada jadwal pertama, mengakibatkan keterlambatan pada jadwal berikutnya.

\section{Opportunities}

a. Diferensiasi dari model LCC tradisional dengan menambahkan layanan pelanggan atau operasi sebagai layanan penerbangan penuh dengan tarif rendah.

b. Konsolidasi industri berkelanjutan telah membuka peluang untuk rute baru dan bekerjasama dengan bandara terkait.

4. Threats

a. Maskapai dengan layanan penuh mulai memangkas biaya untuk dapat bersaing.

b. Hadirnya maskapai penerbangan lain dengan konsep LCC ke pasar industri.

c. Peraturan penerbangan dan kebijakan pemerintah.

d. Sistem gangguan karena bergantung pada penjualan secara online.

F. Analisis Blue Ocean Strategi

1. Strategi Kanvas, merangkum faktor-faktor yang dijadikan ajang kompetisi

Terdapat 3 faktor yang saat ini dijadikan kompetisi dalam industri maskapai penerbangan Air Asia, yaitu :

a. Harga: Air Asia dengan cermat melakukan penetrasi harga murah dan berbeda dengan maskapai penerbangan lainnya, belum lagi dengan promo-promo yang mereka tawarkan. Stigma bahwa berlibur dengan menggunakan pesawat itu mahal pun sirna ketika penawaran yang ditawarkan Air Asia.

b. Kualitas pelayanan: Air Asia beranggapan salah satu strategi untuk merebut hati penumpang pesawat adalah peningkatan kualitas pelayanan. Air Asia berusaha meningkatkan On Time Performance (OTP). Dengan ketepatan waktu penerbangan, mampu membuat nyaman calon penumpang. Budaya Air Asia memberikan pelayanan yang terbaik, kenyamanan dalam kabin pesawat, para karyawan juga sudah terampil dalam melayani penumpang.

c. Rute penerbangan: perluasan rute penerbangan terus dilakukan oleh Air Asia. Terutama untuk rute bagi wisawatan yang ingin berlibur ke tempat-tempat wisata.

2. Kerangka Kerja Empat Langkah 
a. Faktor yang harus dihapuskan dari faktor-faktor yang telah diterima begitu saja oleh industri.

1). Mengurangi biaya dengan tidak menyediakan menu makanan atau minuman bagi penumpang.

2). Pemesanan tiket melalui internet atau membeli ke konter dengan bentuk tiket selembar kertas. Dengan tiket selembar kertas, maka pemborosan biaya dapat dilakukan.

b. Faktor yang harus dikurangi hingga dibawah industri

1). Mengurangi penerbangan dari satu daerah ke daerah atau dari satu negara ke negara lain menggunakan transit.

2). Konter tiket pesawat sangat sedikit dan biasanya pesanan tiket melalui media internet. Hal ini dilakukan agar sedikit mempergunakan tenaga kerja seperti agen tiket dan penjaga konter, sehingga pembebanan biaya tenaga kerja dapat diminimalkan.

c. Faktor yang harus ditingkatkan hingga diatas standar industri

1). Mempertahankan brand image yang sudah terbentuk positif di benak konsumen. Hingga saat ini, armada yang dimiliki Air Asia tipe Airbus A320. Penambahan pesawat ini dilakukan untuk menghubungkan Air Asia yang ada di Indonesia. Saat ini Air Asia mempunyai 5 hub diantaranya di Medan, Surabaya, Jakarta, Denpasar dan lainnya.

2). Harga lebih kompetitif. Maskapai penerbangan Air Asia berusaha memberikan harga yang kompetitif. Maskapai penerbangan Air Asia akan terus memberikan kualitas pelayanan dengan harga yang masih kompetitif. Selanjutnya, Air Asia gencar mengadakan program promosi dan memberikan promo secara regular setiap Minggu.

4). Penggunaan peralatan yang lebih modern. Dengan layanan yang disediakan oleh Air Asia, penumpang dapat melakukan check-in sendiri secara online untuk penerbangan mereka, memilih tempat duduk sendiri, dan dapat juga mencetak boarding pass sendiri.

d. Faktor yang belum pernah ditawarkan industri sehingga harus diciptakan

Menciptakan moto yang memikat "Now Everyone Can Fly" dengan penawaran tiket yang murah dan memberikan tiket promo secara reguler Air Asia mampu memberangkatkan semua orang.

3. Menjangkau Melampaui Permintaan yang Ada Maskapai penerbangan Air Asia "Now Everyone Can Fly" tertulis di setiap badan pesawat Air Asia.Slogan tersebut membuat orang bisa menikmati perjalanan udara. Di Indonesia, transportasi udara sebelumnya identik dengan kalangan menengah atas. Tarif pesawat terbang lebih mahal dibandingkan transportasi darat atau laut. Sehingga hanya kalangan atas yang bisa menggunakan transportasi tersebut. Namun, hadirnya Air Asia berhasil merubah pandangan itu. Dengan mempertahankan layanan LCC, Air Asia bisa tetap memberi tarif murah yang terjangkau bagi semua kalangan.

4. Menjalankan Strategik dengan Benar

a. Utilitas bagi pembeli: layanan jasa Air Asia dilakukan melalui perkembangan teknologi informasi dapat menciptakan kemudahan dan kenyamanan bagi pelanggan Air Asia.

b. Harga: dalam menetapkan harga, perusahaan dapat menetapkan harga sesuai kualitas dari masing-masing produk. Penetapan harga juga dengan memperhitungkan nilai atas manfaatmanfaat yang akan diterima oleh pembeli, namun tetap berorientasi pada harga pesaing.

c. Biaya: Air Asia tidak bergantung pada penjualan melalui agen perjalanan. Ini berarti bahwa maskapai tidak membayar komisi apapun ke agen perjalanan, jika dilakukan bisa berdampak pada harga tiket. Air Asia juga tidak menggunakan agen perjalanan, atau berpartisipasi dalam sistem reservasi seluruh dunia dapat menghemat biaya.

d. Pengadopsian:pesawat harus terbang sesering mungkin, penerbangan pertama tinggal landas sepagi mungkin secara komersial dan penerbangan terakhir secara khusus terbang pada tengah malam.Masa perputaran pesawat Air Asia adalah 25 menit, dibandingkan dengan maskapai lain yang masa perputarannya 1 jam.

\section{G. Pembahasan}

Berdasarkan hasil penelitian diperoleh hasil bahwa variabel inovasi nilai berpengaruh terhadap keunggulan kompetitif pada maskapai penerbangan Air Asia. Terdapatnya pengaruh variabel inovasi nilai terhadap keunggulan kompetitif pada maskapai penerbangan Air Asia, mengindikasikan bahwa Air Asia mampu mempengaruhi pelanggan untuk Air Asia sebagai moda transportasi udara.

Berdasarkan hasil penelitian secara kuantitatif diperoleh hasil bahwa terdapat pengaruh yang signifikan variabel inovasi nilai terhadap keunggulan kompetitif. Hasil penelitian ini konsisten dengan penelitian yang dilakukan oleh Chaoren (2011) dengan judul "Use Value Innovation to Create Competitive Advantage in Blue Ocean". Hasil penelitian menunjukkan bahwa ada keterkaitan antara inovasi nilai dengan keunggulan kompetitif. Inovasi nilai dapat menciptakan keunggulan kompetitif pada strategi blue ocean. Inovasi nilai menjadi acuan dalam menciptakan keunggulan kompetitif sehingga membuat IKEA di Nanjing sukses menerapkan blue ocean.

Penelitian kemudian diperkuat dengan menggunakan metode kualitatif. Berdasarkan 
pernyataan dari pelanggan Air Asia, tour guide, event organizer, dan agen tiket dapat diketahui bahwa inovasi nilai yang dilakukan oleh Air Asia berupa kenyamanan dalam kabin pesawat dan pemesanan tiket secara online mempunyai pengaruh terhadap keunggulan kompetitif yang terdiri dari keterampilan karyawan, rute penerbangan, harga tiket, dan on time performance.

Sebagaimana dijelaskan dalam teori dapat dikatakan bahwa inovasi nilai diciptakan dalam wilayah dimana tindakan perusahaan secara positif mempengaruhi struktur biaya dan tawaran bagi pembeli. Penghematan biaya dilakukan dengan menghilangkan dan mengurangi faktor-faktor yang menjadi titik persaingan dalam industri.

Selanjutnya peneliti membahas mengenai analisis SWOT Air Asia. Dengan mengenali kekuatan dan kelemahan serta pemahaman dari ancaman dan peluang merupakan hal yang penting dilakukan dalam menjabarkan strategi perusahaan ke dalam langkah-langkah strategis pada tingkat bisnis unit.

Dari analisis yang telah dilakukan dapat disimpulkan bahwa Air Asia tetap mampu mempertahankan kesuksesannya, mengingat strength yang dimiliki oleh penerbangan tersebut, sebagai pelopor maskapai penerbangan dengan biaya murah. Selain itu terkait dengan kelemahan yang dimiliki oleh Air Asia selama ini tidak mengurangi minat para pelanggan untuk menggunakan maskapai penerbangan Air Asia. Mengenai ancaman dari luar sebagian besar telah mampu diatasi oleh Air Asia, misalnya saja mengenai pesaing baru yang telah muncul untuk mengungguli Air Asia, sebagai pelopor LCC yang datang lebih awal dibandingkan dengan maskapai lainnya ini tentunya berdampak baik bagi Air Asia, sebab dengan ini Air Asia akan lebih mendapatkan tempat di hati para pelanggan.

Dalam Blue Ocean Strategy (BOS) faktor-faktor yang berkaitan dengan upaya untuk memenangkan kompetisi tidak lagi menjadi patokan. Sebaliknya, BOS memiliki suatu logika strategis yang menjadi kunci utamanya, yang disebut dengan inovasi nilai. Inovasi nilai memiliki konsep yaitu bagaiamana menciptakan diferensiasi dan biaya rendah di saat bersamaan. Blue ocean yang efektif seperti strategi yang dikembangkan memiliki tiga kualitas yang saling melengkapi menurut Kim dan Mauborgne (2006), yaitu:

1. Fokus: setiap strategi memiliki fokus pada suatu profil strategis atau kurva nilai perusahaan harus dengan jelas menunjukkan fokus tersebut. Maskapai penerbangan Air Asia fokus pada tiga faktor: pelayanan yang baik, kecepatan, dan menerbangkan semua orang denganpoint to point tanpa transit. Dengan fokus seperti ini, Air Asia mampu bersaing dalam soal harga. Air Asia tidak perlu menambah keuntungan dari fasilitas makan, cetak tiket, dan pilihan kursi. Sebaliknya pesaing lain berinvestasi pada semua faktor atau full service. Sehingga membuat pesaing lain sulit untuk diikuti oleh pesaing lain.

2. Divergensi/gerak menjauh: ketika strategi suatu perusahaan dibentuk secara reaktif dalam usaha mengikuti irama kompetisi, strategi ini akan kehilangan keunikannya. Jika pada maskapai penerbangan menyediakan fasilitas makanan dan terdapatnya tempat duduk kelas ekonomi dan bisnis, maka pada strategi cenderung memiliki profil yang sama. Memang dalam pasar maskapai penerbangan Air Asia para pesaing indsutri hampir identik. Misalnya saja para pesaing industri sudah memberlakukan sistem reservasi online, memberlakukan konsep LCC. Untuk bisa dikatakan masuk ke blue ocean, kurva nilai perusahaan harus lebih menonjol. Oleh karena itu dengan menerapkan empat langkah: menghilangkan, mengurangi, meningkatkan, dan menciptakan dapat membantu membedakan profil Air Asia dengan pesaing lain.

3. Moto yang memikat: sebuah strategi yang baik memiliki moto yang jelas dan memikat. "Now everyone can fly", inilah moto dari maskapai penerbangan Air Asia. Maskapai penerbangan Air Asia bisa menerbangkan semua orang dengan menawarkan biaya perjalanan yang murah baik perjalanan dalam negeri maupun luar negeri.

IV. Kesimpulan, Keterbatasan Penelitian, Saran.

Dalam penelitian ini, peneliti mencoba menjawab pertanyaan bagaimana penggunaan inovasi nilai untuk menciptakan keunggulan kompetitif pada strategi blue ocean. Berdasarkan analisis data yang telah dilakukan, maka dapat ditarik kesimpulan sebagai berikut: Dalam penelitian ini, peneliti mencoba menjawab pertanyaan bagaimana penggunaan inovasi nilai untuk menciptakan keunggulan kompetitif pada strategi blue ocean. Berdasarkan analisis data yang telah dilakukan, maka dapat ditarik kesimpulan sebagai berikut:

Berdasarkan hasil penelitian diperoleh hasil bahwa variabel inovasi nilai berpengaruh terhadap keunggulan kompetitif pada maskapai penerbangan Air Asia. Penelitian kemudian diperkuat dengan menggunakan metode kualitatif. Berdasarkan pernyataan dari pelanggan Air Asia, tour guide, event organizer, dan agen tiket dapat diketahui bahwa inovasi nilai yang dilakukan oleh Air Asia berupa kenyamanan dalam kabin pesawat dan pemesanan tiket secara online mempunyai pengaruh terhadap keunggulan bersaing yang terdiri dari keterampilan karyawan, rute penerbangan, harga tiket, dan on time performance.

Air Asia tetap mampu mempertahankan kesuksesannya, mengingat strength yang dimiliki 
oleh penerbangan dengan biaya murah. Blue ocean yang efektif seperti strategi yang dikembangkan memiliki tiga kualitas yang saling melengkapi menurut Kim dan Mauborgne (2006), yaitu: fokus, divergensi dan moto yang memikat. Maskapai penerbangan Air Asia fokus pada tiga faktor: pelayanan yang baik, kecepatan, dan menerbangkan semua orang dan point to point tanpa transit. Divergensi: menerapkan empat langkah, yaitu menghilangkan, mengurangi, meningkatkan, dan menciptakan, Air Asia juga memiliki moto yang memikat.

\subsection{Keterbatasan Penelitian}

Pada penelitian ini terdapat beberapa keterbatasan sebagai berikut:

1. Keterbatasan terletak pada objek penelitian yaitu pada pengguna Air Asia, tour guide, event organizer dan agen tiket, ada kemungkinan hasil penelitian ini akan lebih baik jika objek penelitian dan responden penelitiannya pada karyawan dan pengelola Air Asia.

2. Kuisioner yang disebarkan sebanyak 120 melalui via email dan secara secara langsung, namun hasil di lapangan kuisioner yang kembali sebanyak 96 kuisioner.

\subsection{Saran}

Berdasarkan hasil penelitian yang telah diperoleh, maka peneliti memberikan beberapa saran sebagai berikut dengan harapan dapat memeberikan manfaat bagi pihak manajemen maskapai penerbangan Air Asia dalam meningkatkan penggunaan inovasi nilai sehingga dapat lebih meningkatkan keunggulan kompetitif.

1. Saran praktis bagi untuk pengelola Air Asia agar meningkatkan kualitas pelayanan dilihat dari segi on time performance dan tingkat pelayanannya lebih maksimal lagi untuk membuat ekuitas merek tertanam di benak masyarakat sehingga mampu menciptakan keunggulan kompetitif.

2. Untuk penelitian selanjutnya dapat melihat keterbatasan-keterbatasan pada penelitian ini yang dapat dijadikan sumber ide bagi pengembangan penelitian di masa yang akan datang. Pendekatan penelitian modifikasi variabel dan alat analisis akan dapat membantu terhadap penggunaan inovasi nilai untuk meningkatkan keunggulan kompetitif pada maskapai penerbangan Air Asia.

\section{DAFTAR PUSTAKA} Kim, W. Chan dan Mouborgne, Renee. 2006 , Ilmu Semesta.

Porter, Michael E. 1994, "Keunggulan Bersaing”, Jakarta: Binapura Aksara.

Santoso, Singgih dan Tjipjono, Fandy. 2001, "Riset Pemasaran: Konsep dan Aplikasi dengan SPSS, Jakarta: PT. Elex Media Komputindo.
Djarwanto dan Subagyo, Pangestu. 1996, "Statistik Induktif", Yogyakarta: BPEE

Margono. 2010, "Metodologi Penelitian Pendidikan", Jakarta: Rineka Cipta.

Sugiyono. 2014. "Metode Penelitian Kombinasi (Mixed Method)", Bandung: Alfabeta.

Moloeng, Lexy J. 2007, "Metodologi Penelitian Kualitatif”, Bandung: 'PT Remaja Rosdakarya Offset.

Robert, W. Woodruff. 1997, "Customer Value: The Next Source for Competitive Advantage", Journal of Academy of Marketing Science. Volume 25 No. 2, hal 139153. Spring.

Pramudita, Yoana Ariana dan Japarianto, Erwin. "Analisa Pengaruh Customer Value dan Customer Experience Terhadap Customer Satisfaction De Kasteel Resto Surabaya", Jurnal Manajemen Pemasaran Petra Vol. 1, No 1, (2013) 1-7.

Mulyadi, 2002, "Akuntansi Biaya Edisi 5", Yogyakarta: AMPN-YKPN.

Hoffman, K. Douglas dan John E.G. Batenson. 1997, "Essential of Service Marketing", Florida: The Dryan Press.

Kadarningsih, Ana. Media Ekonomi dan Teknologi Informasi Vol. 21 No 1 Maret 2013: Keunggulan Bersaing: Faktor-Faktor yang mempengaruhi dan Dampaknya pada Kinerja Selling-In (Studi pada Outlet Binaan PT. Indosat Semarang).

Parasuraman, A., V. A. Zeithaml, dan L.L. Berry. 1998, "Servqual: A Multiple-Item Scale for Measuring Consumer Perception of Quality", journal of Retailing, Vol. 64, No. 1.

Porter, Michael E. 1985, "Competitif Advantage: Creating and Sustaiing Superior Performance", New York: Macmillan.

Smith, J. Brock dan Donald W. Barcklay. 1999, "Selling Partner Relationship: The Role of Interdependence and Relative Influence Influence", Journal of Personal Selling \& Sales Management, Vol. XIX Number 4, Fall, p. 21-40.

Sekaran, Uma. 2006, "Metodologi Penelitian untuk Bisnis", Jakarta: Salemba Empat.

Mulyadi, 2002, "Akuntansi Biaya Edisi 5", Yogyakarta: AMPN-YKPN.

Ghozali, Imam. 2011, "Aplikasi Analisis Multivariat dengan Program IBM SPSS 19 (edisi kelima)", Semarang: Universitas Erlangga 
